http://dx.doi.org/10.4314/gjl.v8i1.5

\title{
MEANING MODALS: AN INQUIRY INTO THE SEMANTIC CONTENT OF SOME ENGLISH MODALS
}

\author{
Iyabode Omolara Akewo Nwabueze
}

\begin{abstract}
Twenty years of the Beijing Conference has been celebrated in 2015. However, the extent to which women empowerment is expressed in their linguistic choices remain an issue of interest to linguists. Modal verbs as propositional elements that can reveal women's power self-expression has not been much investigated. This study thus set out to investigate the meaning content that these grammatical elements possess in relation to their usages by women as syntactic elements expressing their perception of their power positioning within the Nigerian psychosocial milieu. Data were collected using sample extracts taken from newspaper articles expressing women linguistic usages of English modal verbs. An analysis of the modal system based on the SFG theory was applied to the collected data. An interrogation of the modals reveals propositional content of the modals within the syntactic structures in which they occurred. It was found that the modal verbs as employed by Nigerian women in the newspaper articles indicate that the perception of the women in terms of their ability to assert their power within the Nigerian society is yet to fully materialise. Instead, the finding indicates their continued hegemonic consent to the patriarchal social order. It was thus concluded that modals not only possess semantic content within syntactic usages, their usages by Nigerian women have propositional contents that are not fully self-assertive but rather hegemonic in its support of patriarchy.
\end{abstract}

Keywords: English modals, women assertiveness, newspaper articles, linguistic choices, semantic content

\section{Introduction}

Modality has usually been viewed as a grammatical concept within the syntactic tradition. It is more often than not viewed as an auxiliary verb. Within the Systemic Functional Grammar (SFG), it is viewed essentially as a part of the subsystem of mood. The familiar thinking is to see modals as the support for main verbs. Its meaning content is thus not usually the focus in the discourse within the major syntactic traditions. This 
work thus seeks to query the semantic content that some modals have within the syntactic structures in which they occur. This is looked at from the angle of the modals as it relates to gender power positioning. This study therefore investigates the meaning content of modals in the syntactic structures of women in their linguistic usages in some Nigerian newspapers.

The gender contest between women and men have been quite confrontational. It is now twenty years since the time of the Beijing Conference. The question is: have Nigerian women's linguistic employments been able to match the expected success of the conference. This paper seeks answers to the modal usages in the syntactic structures in women's linguistic employments since after the conference in 1995. It is important to look at the propositional content of the modals in the linguistic employment of women. The seeming inconsequential nature of modal verbs, when seen as mere helping verbs to the main verbs, within the syntactic tradition makes them of interest to this study.

The paper investigates the semantic content of women linguistic employments in select Nigerian newspapers. It is expected that the modal choices they make should express their psychological perception of their power positioning within the society.

Traditionally, modals are usually considered as performing grammatical functions within syntactic structures. This study seeks to ascertain if semantic content can actually be ascribed to them beyond there mere grammatical functions, especially, in relation to women empowerment expressed in language. Their ability to possess semantic content that expresses the women's self-perception will thus indicate their functioning beyond mere grammatical appendages in the women's choices of syntactic structures. The next section therefore looks at the concept of the modal system within the Systemic Functional Grammar.

\section{The Modality System}

The interpersonal function of language has to do with the relationship between participants in a communication event. It denotes the perception held by the addresser of her/his relationship to the addressee. Halliday and Matthiessen (2014) assert that both polarity and modality are realised through the mood system in Systemic Grammar. The realisation could be through the finite modal or through the modal adjunct. Halliday (1985) as well as Halliday and Matthiessen (2014) note that the following semantic categories of giving information (statement), demanding information (question), and demanding services or goods (commands) are features prevalent in the mood system. Opara (2005) opines that interpersonal function of language is "realized in the clause mood and modality" (p. 120).

In addition, the mood system influences the choices in the lexico-grammar. Osisanwo 
(1999) states that it essentially has to do with the presence or absence of a subject in the sentence. Opara (2005), following Melrose (1995), declares that it affects the choice of the modality in the structure and the intonational type. While the indicative mood is propositionally expressive or demanding, the imperative mood normally lacks subject and is 'goods and services' demanding - that is, a command (Halliday 1985: 68). The focus in this study, however, is the modality subsystem of mood as an indicator of the woman in the powerful position of demanding goods and services or commanding as a sign of empowerment.

Opara (2005: 120) further states that the mood system can be divided into the "Mood Block (Modal Finite and Adjuncts) and Residue." Subjects and finites are the two main elements in the Mood Block. The Finite is called the Modal Finite because it expresses the speaker's opinion about the probability or certainty of the proposition made. The modal finites, he says, are modal verbs of English such as may, might, is to, was to, ought to, need, has to, had to, did, and so on. The modal adjuncts, the second element in the mood block, are elements that "temper or modify the argument of the proposition or proposal." They therefore carry interpersonal meaning and express probability as in perhaps, maybe, probably; or intensification or minimisation like really, absolutely, just; or obligation and inclination as in happily, willingly. They could also express usuality as usually or sometimes. The question then is: what is modality?

Halliday (1985) defines modality as

the speaker's judgement of the probabilities, or the obligations, involved in what he is saying. A proposition may become arguable as being likely or unlikely, desirable or undesirable - in other words, its relevance specified in modal terms (p. 75).

Halliday and Matthiessen (2014: 172) see modality "as the speaker's judgement, or request of the judgement of the listener, on the status of what is being said." They further describe modality as the intermediate degrees between the positive and negative poles, adding that "what the modality system does is to construe the region of uncertainty that lies between 'yes' and 'no"' (p. 176).

In essence, modality is an expression of the speaker's opinion/view of the propositional content (information)/proposal (goods and services demanded) and the addressee; and their relation to him/herself. Halliday (1985), however, uses the term modulation for that which expresses the degree of likelihood for obligation and inclination expressed by the speaker as against strict modality for propositions as it occurs in probability and usuality. This is the exact position held by Halliday and Matthiessen (2014). The interactional nature of modality puts it under the general description of clause as exchange ((Halliday and Matthiessen, 2014). 
The modality system is presented below, adapted from Halliday and Matthiessen (2014: 182):

Fig. 1: The System of Modality

The semantic possibility of each type is presented in a tabular form below.

Table 1: The semantic extension of the modal system

\begin{tabular}{|l|l|l|l|}
\hline Probability & Usuality & Obligation & Inclination \\
\hline certain & always & required & determined \\
\hline probable & usual & supposed & keen \\
\hline possible & sometimes & allowed & willing \\
\hline
\end{tabular}

Conversely, Palmer (1977) differentiates between mood and modality. He sees mood as grammatical, whereas modality relates to the speaker's commitment. He says that volition is modal as contained in the modal verbs will and can. He does not treat modality as a subsystem of mood. This seems to also be the position of Osisanwo (1999) in his treatment of modality as an independent element within the predicate unit in his explication.

Palmer (1977) gives the definition of modality as referring to "the meaning of modal verbs" (p. 1). His discussion is centred on the use of modals to express actuality of "EVENT" [(p.1) original capitalisation]. This event is the full/main verb. To him, an event's occurrence can be indicated by the modal preceding the verb. He describes actuality as the event being actualised "in certain circumstances" (p. 1). He discusses the modals can and will as probable candidates for the realisation of the actuality of events in these certain circumstances. He notes that these same modals can be used as main verbs. However, he submits that determining these modals' grammatical functions in particular instances can be confusing. He posits that the supposed past tense of these modals should not be so regarded as they actually do portray an entirely different meaning content in use. Thus, can and could cannot be regarded as indicative of only tense difference as their conveyance of ability is different. Consequently, while can will be predictive of actuality of occurrence of the event, could will not simply because the predictive, futuristic tendency of can of an ability cannot be regarded as a possibility of the past. The difference between these two sentences should illustrate this.

1. I can run to the tree, but I shan't.

2. *I could run to the tree, but I shan't.

In analysing the sentences above, Palmer (1977) argues that (1) could be regarded as 
both ability and possibility of actuality with the possibility of occurrence, while (2) does not seem probable because actuality is not realised in an improbable past nonoccurrence. What this means is that if I could run to the tree, say last year, it should also be only probable then, and it might not have been actualised because I possibly never did. But if I can now, the possibility is higher that I will. The present ability thus indicates possibility of a future actuality without necessarily leading to an actual occurrence. Other factors may decide that eventuality. It should be borne in mind that other uses are made of could which may also be present as in polite request. He also discussed this difference in the case of will and would. While he sees will as being used for volition functions with strong futuristic actuality content, would does not perform such a function. Thus,

3. I will call you.

seems more credible, volitive and predictive of actualisation than

4. I would call you.

The speaker in (3) appears more committed to bringing the event to pass.

He also states that the volition of will is stronger than that of can. His argument is that one may have the ability but not have the readiness to carry out the event.

5. I can sack you.

indicates the ability and possibility of the speaker to carry out the event while

6. I will sack you.

is not only indicative of ability, it is actually more of a promise to perform the action; suggesting the possibility of actualisation.

In a more recent study on mood and modality, Palmer (2001:1) sees modality as being concerned with "the status of the proposition that described the event". He asserts that modality differs from tense and aspect in the sense that it does not have direct reference to an event but rather to the status of the event. In essence, one could actually relate the discussion here to the argument above. The essential difference here is that the concept of 'realis' and 'irrealis' are made prominent in this work, suggesting that the actualisation or non-actualisation of the event could be categorised as either of these. However, it should be noted that the realis has to do with the actualisation of the event as opposed to the irrealis, which has to do with the imagined and probably not realised event. Nonetheless, he accepts the fact that these concepts could be quite vague in 
describing the modal structure of languages. For this reason, probably, he applied the concepts to the analysis of data from different languages. Palmer (2001) further argues that languages tend to represent modality grammatically in terms of modal systems or mood. As noted above, the modal system is used as the base of the discussion in this paper.

On his part, Hakutani (1978) presents the features of modality. He opines that it is regarded as optional though it plays a unique role in the sentence. It has some unique features that main verbs do not usually have even though it is normally viewed as the auxiliary or helper of the verb. He notes that it always occurs before the infinitive verb form and never inflected for the third person singular. He also links modals semantically to mood, stating that its purpose in the sentence is "to signal a hypothetical or factual situation" (p. 59). This could be realised as "possibility, necessity, ability, obligation, intention, permission, assertion, and futurity" (p. 59).

He contends that the limiting of English modals to may, can, shall, will, and must in the Traditional Grammar is a disservice to the flexible and dynamic nature of the language. He identifies other modals of English as including need, dare and the so-called past forms like might, could, should, would. In addition, he categorises some other elements that are not traditionally grouped with the above such as be going to, have to which he finds comparable to will and must in function "though they are not exactly the same" (p. 59). He postulates the need to re-classify the English modals to incorporate these new 'modal-like' expressions.

Hakutani (1978) notes that the most obvious characteristic feature of a modal is that it takes a subsidiary position in relation to its main verb. Thus, in sentences like

7. He may understand.

8. $\quad\left(\mathrm{He}_{\mathrm{i}}\right.$ wants (he $\mathrm{i}$ (to) understand))

may is a modal while want is actually a main verb of the matrix clause. Understand is being modified in (7) while understand of (8) is actually the verb of an embedded clause. To him, an important feature in differentiating prospective modal candidates from other types of elements is their function within the syntactic unit.

The modal-like expressions he calls quasi-modals, while the original forms retain their names as modals. Thus, have to, be going to, be about to, be to, be able to, and be unable to are quasi-modals while may, might, can, could, will, would, shall, should, must, need, dare, ought to, used to, had better, had best, and had rather are modals.

Hakutani (1978) also observes that these 'modals' have some differences. A major difference between them is that, while modals are not derivable, the quasi-modals have 
high probability of having been derived. This can be seen in the following illustration: I am going to have to work from I am going to and I have to work. Secondly, their syntactic behaviours differentiate them. While modals are usually found in the initial elements of the verb phrase, quasi-modals tend to be able to combine indefinitely.

9. I' $l l$ shatter the mystique of under-performance.

10. Mary might have been unable to have completed the test before 9 a.m.

The modality system is evidently an important element in interpersonal relationships as could be perceived from the discussions of the various scholars. We however wish to observe that since our focus is mainly on the relevance of the modality system as a means of the woman letting her audience know that she is in charge, the semantic elements in these syntactic systems are of interest to us in this discussion. Her degree of enforcing obligation to provide undertaking to her propositions and proposals are especially useful here. The actuality of this undertaking or performance by the addressee is vital. Nonetheless, the level of her demand for the undertaking indicates her volitional ability to demand for goods and services. This places her in a powerful position. Other factors may come into play to affect the undertaking where they are not immediately provided. We take cognisance of this in our interrogation. Consequently, the Systemic Functional Grammar serves as the base of our inquiry while the semantic thrust of Palmer's description builds on this. Hakutani's focus on syntactic structuring of the modal helps to show the consequence of the place of the modal positioning in the structure as indicative of the forcefulness of the demand in the proposal.

As a consequence, Ellen Johnson Sirleaf's statement (Asante 2006: 23) used as an example in (9) is indicative of a woman that is full of volition, force and promise. In short, she has successfully indicated her ability, performed the speech act of promising and threatening, depending on the moral rectitude of her listener, and displayed power befitting her status as the president of a modern nation. The issue here is not of a 'weaker sex' but of a focused and powerful leader. Her modal choice shows this. She is not just able but willing and going to perform the action (actualising) of 'shattering', another forceful word. The analysis is intended to uncover if this sort of mood predominates in the language of women as presented in Nigerian newspapers.

Nonetheless, we need to mention that some works (cf. Papafragou 1998; von Fintel 2005 ) with actual focus on the semantic description of modals are noted. However, the base of the discussion here is to see how the semantic structuring of modals occurs within the syntactic structures in SFG. Consequently, this study may not be overtly concerned with the core semantic analysis such as the truth conditions of propositions but more with the semantic contents of the modal verbs within sentence structures used by women to indicate their ability to make proposals and demand for goods and services within the SFG tradition as discussed above. 


\section{Methodology}

The study is a survey design. It largely involves uncovering the role played by women in the sustenance of the patriarchal social structure to the detriment of their own empowerment. It specifically seeks to find out the assertiveness level of Nigerian women as reflected in their language in select Nigerian newspapers. The use of modal verbs to indicate their ability to actualise their demand for goods and services in the Hallidayan sense, to define their relationship to their interlocutors, is investigated. This is premised on the assumption that, with the women global conference on empowerment, it is natural to expect that Nigerian women should be able to assert force and exude confidence in their linguistic choices and inter-relational discourses.

Data were collected from seven Nigerian daily newspapers. The type of discourse used include texts created by women and those that are focused on women. Essentially, the texts were chosen based on their having some relationship with women. However, the selection of the modals has to do basically with those in which women created the particular sentential structures or are the topic focus in the sentences. In some sense, they must be making use of language to express themselves. This is in order to do a modal assessment to determine the level of goods and services demanding forces of the proposals contained in such sentential structures.

The newspapers used as data source are The Guardian (TG), The Punch (TP), Nigerian Tribune (NT), New Nigeria (NN), The Sun (TS), This Day (TD) and The Comet (TC). They were chosen purposively because they have national coverage and distribution. This is in line with the conceptual definition given by Reah (1998) concerning the classification of a national or international newspaper.

The chosen newspapers cover the time period beginning from September 2005 to December 2006. September 2005 marked the tenth anniversary of the Beijing Conference. September 2015 thus makes it exactly twenty years since the conference took place. This was recalled and a march done to celebrate this in Abuja, Nigeria as shown on the Nigerian national television, NTA. In our view, the continued negativity on women and vulnerability of women to violence suggests that women are yet to achieve the hoped-for success with the Beijing Conference.

\section{Data Analysis and Discussion}

Actuality of event is not always a certainty in the modal system (Palmer 1977; Reah 1998: 94). It is, therefore, important to know that the use of a particular modal 
may not necessarily indicate that the event has occurred. The propositional content of the modal is also merely a proposition until it has actual occurrence. In the light of this, the employment of modals by women in the data and the implication it has for their assertiveness level in the communication event is presented below. Only those clauses perceived to have modal finites, modal adjuncts (Halliday 1985; Opara 2005), or quasimodals (Hakutani 1978; Halliday and Mattheissen 2014) are culled from the data.

The modal forms are grouped into different subsystems of interpersonal meaning content to define the functioning of their modality. The grouping chiefly follows the scholars discussed above but with a redefinition and an integration of their delineation, where necessary, to get the best from the data (The full texts/structures from which modal forms were extracted is presented in the appendix.).

In the same vein, each article is coded, using the newspaper name in an abbreviated form. For instance, The Guardian is TG, New Nigerian is NN, etc. These are then given numbers to indicate their position in the coding system. For example, TG01, NN02, etc. The number of modals identified in each article is indicated beside each coded article. These are then grouped under each metaphoric/semantic content they belong as shown in Table 2 below.

It however needs to be mentioned that this paper is a part of a larger research work. The full article texts are attached to the full thesis (Daniel 2008) from which this paper is extracted. Adding each article to this paper would have made it unnecessarily bulky. Consequently, extracted texts in which modals occurred, irrespective of the text type, were used as data, using the convenience sampling procedure. These are the texts identified, coded, classified, analysed and discussed below. The modals as used in the sentence/clause structures are presented in bold fonts for easy reference as they are discussed.

Table 2: Modal Choices and their Propositional Contents

\begin{tabular}{lll}
\hline Modality & Text examples & Freque \\
\hline Probability & $\begin{array}{l}\text { may NT12; may need to TP03; would have TD13; should NT12; would } \\
\text { have TG14; wouldn't have TG09; would not TG01; might TP17 }\end{array}$ \\
& $\begin{array}{ll}\text { always NN02, NT01, TC01, TD07, TD15, TG02, TG18b; must always } \\
\text { Usuality }\end{array}$ & TD15; used to TC02, TG03, TP02; would TP05; will always TP17
\end{tabular}


$\begin{array}{ll}\text { Obligation } & \text { must NN10, NT11, TC01, TD06, TD15, TP02; would have to NN10; } \\ \text { cannot TD07; have to TD07, TD13, TG01, TG18a, TP09; should TD15, } \\ \text { TG04, TG14, TG16; may need TP03; must always TD15; had to TG01; } \\ \text { must be TG16; should have TG17; has to TP09; }\end{array}$

$23(25.27)$

Inclination almost TC05; will TC06; would TD05, TD14, TG18b; would have TD14, TG18a; would have really TG03; can TG03; cannot TP17; can TP17; will never TP09
Ability
can't, can NN03; can NT07, NT12, TD14, TG03, TP17; would not be able to TD09; could TD13, TD15; couldn't TG09; could not TG16; can hardly TP09

Futurity/ will NN02, NT07, NT11, TD05, TP02, TP09, TP17; would TD09, TD15, 13 (14.28) willingness TG01, TG16; was going to TD13; shall TP14

Intensification strongly NN04; surely, NT07; actually TG03; promptly TP14; really 7 (7.69) NN03, TC01; just TG01

Minimisation really TG03; hardly TP09; never TP09

Eight types of modality are identified in the analysed texts as presented in Table 2 above. They are probability, usuality, obligation, inclination, ability, futurity and willingness, intensification, and minimisation. All of them are discussed under each analysis. Futurity and willingness are, however, combined because they tend to function along the same line in the data. The willingness to perform the action suggests the likelihood of its occurrence in the future, potentiality identified by Halliday and Matthiessen (2014) and the actuality of Palmer (1977).

A look at the modal choices reveals a preponderance of the obligatory type, $25.3 \%$ of the total analysed modals as presented in Table 2 . In other words, the speaker seems to expect the addressee to be obliged to perform an action. However, a critical look at the addresser's audience reveals that in almost all the cases of obligation, the woman is the one being put under the obligatory role. TD06 makes the woman addresser the obliged person, so also does NN10.

NN10 I must confess that the person I married is part of the
contributory factors to what I have become today
TD06 I must do the work required of me to remain there However, the difference between the two of women in these two different interviews is 
that TD06 is compelling herself to assert her need for hard-work as a pre-requisite for the maintenance of her successful business. Such an obligation appears positive and self-deterministic.

The obligatory state of TG04 is another matter entirely. The addresser expects other females to act in a particular way. The main point of interest is not really the relationship between them but her perception of the addressees as having failed in their responsibilities hitherto. This reveals a superior air which makes her insist on their taking up the roles and duties she has assigned them. In essence, she demands:

TG04

(1) Women should refuse to go out...

(2) Mothers should ask their children in power...

(3) Wives should ask their husbands in power...

(4) Sisters should do something to brothers

Though, considering that she was a former Vice-Chancellor of a university (Lagos State University, Ojo, Lagos), one may understand why her modal choice should be so forcefully demanding of obedience; but from other women? In her view, she thinks that Nigerian women of all shades need to compel the males in their lives with any sort of access to power to act for the good of the nation and should thus do something to that end.

This same thrust can be noticed in TG16(4).

TG16(4) ...daughters of the clan who should be by my side traditionally, supported the men this time

In this this text extract from Onwueme's article, it is not the addressee but a third party under obligation. And they, the daughters of the clan (umuada), actually failed the speaker in that they did not fulfil their duties to her as another woman and daughter of their 'sister'. The umuada, instead, supported the men of their clan against their fellow woman. This, naturally, disillusioned the speaker's feminist belief in the unity of women as shown in the extract below.

The experience has also changed her idea of umuada and feminism. She used to be passionate on the Umuada. She like men, though; she adds quickly but takes sides with women. But Tess (Onwueme) says, "But in the march for name, I am going back deflated about some of these things." One of the areas Tess feels betrayed by the umuada is in the area of paying fines. She feels the women took sides with men against her. Tess had, after church service, taken her mother's body straight for burial. But the late woman's family said Tess committed a crime by not bringing the body first for them to pay their last respect. The men had 
sat in Tess' compound debating how much to fine her. In the end, the men fined her four goats. The umuada fined her five goats and other things for the same offence... "I was fined a goat. They let that go. But I was shocked when umuada, the daughters of the clan who should be by my side traditionally, supported the men this time. I paid three fines to the umuada. First, they said my mother did not attend their meetings. Yet, I paid the men." [TG16(4)]

This may be linked to many of the cases of the maleficiary role assigned to the female under theta theory analysis of newspaper article headings in Daniel (2008), which are said to be due to the negative agency of other women. The persistent problem of women not being able to bond has remained a major hindrance in the advancement of the female cause. Lorde (1994) notes that as long as women exploit other women for their own benefit, no matter how legitimate, the female cause may never really attain its full realisation. Women's exercise of power on other women towards negative ends is a negative kind of power which suffers from the same illegitimacy of coercive power that is exercised by the wife-battering husband (cf. Galbraith 1983; Awake! 2008).

It, nonetheless, needs be said that it is not in all cases of women putting other women under obligation that one may consider their position as negative. In TD15, it may be considered more of an encouragement for the woman to take her place seeing the odds against her succeeding in the Nigerian socio-cultural milieu. This is why the interviewee in the article from where the extract was taken notes that women are not only under obligation to be strong, but also to habitually remember that life needs to be lived to the utmost when one has it. No situation should be enough to stop their goal of self-actualisation.

TD15

(1) I was convinced that I could go on to greater success in life

(2) Furthermore, I have always been a very independent person

(3) ... and believed that I would still become successful in spite of this set back

(4) My advice to fellow women is that they should be strong

(5) I must emphasize that women should be strong

(6) Women must always remember that...life must go on

Again, despite the apparent positive nature of this article, the obligatoriness is still female targeted as shown by the pronoun 'I' used by the speaker as well as the noun phrase 'fellow women' in TD15(4). Moreover, it supports the findings so far that the woman is still very much at the mercy of socio-cultural forces that have been against her self-actualisation.

In some cases, like in TG01 and TP09, the woman's sense of obligation most often is 
due to powerlessness. In TG01, she (the woman) is put under obligation to decide between her career and family, which the husband probably never had to. On choosing the family above the career prospect, her new job in the new location must be efficiently managed along with the family to give her best to the two, a demand that is not usually made on the male member of the family. This is why, though she acknowledges the difficulty involved in this feat, her conclusion is that: you just have to manage both. This is not an assertive mindset obviously. She accepts this reality as the only way of tackling this problem. The man must have the benefit while the woman has no other choice than to tag along, no matter how inconveniencing. As such, she praises the husband for his 'understanding'.

Despite the fulfilment of the job, at a point she had to choose between the job and reuniting with her family and career...Upon joining her husband in Lagos, she had to cope with her career as well as building a home...Yet running the home and office, she says, "is not difficult but certainly not easy, but if you manage both properly, you would have a balance". The balancing act, she discloses, was made easier by her "understanding and supportive husband." (TG01)

The woman does not seem to have much choice in the matter as her fulfilment in her job has to be sacrificed while the husband may continue with his. She portrays a cognition that appears very powerless even though she is in a powerful position by the virtue of reaching the peak of her career. One may wonder if Oakley's (1974) argument in Kirby et al (1997: 261) that "the idea that husband's 'help' their wives shows that the responsibility for domestic labour is still seen to lie with women" as oppressive may not be misplaced. If the women themselves see the matter in the light of their being helped, then they are complicit in that purported oppressive practice.

In TP09, however, the woman is faced with a situation of having no choice but to provide for her orphaned grandchildren at so much peril to her wellbeing. Here again, she benefits the society. She sacrifices so much of her old age comfort for the wellbeing of others. So, one wonders when there will be a period of recline for the woman. Probably, for the Nigerian woman, such a period may never really come.

But a very important obligatory role noticed is that in TG17. In this particular situation, the woman is not the one placed under obligatory situation; she is demanding it of another. The woman that is talking here is the Trade Union Congress (TUC) president at the time of the interview. Compared to the women whose modal choices were discussed above, she seems to have taken on a more assertive role as shown in her modal usages.

TG17 She contended that government should have sought out other possible 
solutions

What is interesting about this is that the government of the nation is being engaged or commanded. It is being demanded that the government is under obligation to have provided solution to Nigeria's perennial fuel scarcity and indiscriminate fuel price hikes. This is interesting for the fact that, in many of the articles from which the analysed extracts above were taken, the women are not only soft but their employment of forceful modals usually have other women as target. The rareness of this sort indicates, however, that the woman's clout is still very far from the mainstream of events in Nigeria. Apparently, her position as a labour leader might have helped her to acquire this tough-talking stance. It will be interesting to know if this is her usual manner of talking or it is acquired because of her position.

The most interesting of the texts under obligation is that of TP03. This is not because it is from a woman to other women as noticed in some previous paragraphs but because the women addressed are told that they have an obligation to listen to the male, men of God, tell them how they should live their lives. In the text that has to do with a kind of box pop on the way women dress to church, the writer eventually suggests that for the issue of how women are to dress to be finalised, they may need to hear the opinion of men of God in order to be able to learn the proper way they should, instead of arguing about it. It must be appreciated that the religious leaders wield a lot of influence within the Nigerian context; most of these religious leaders are men. Nigeria being a very religious country, it may explain why the 'men of God' are expected to determine how women should dress.

TP03 ...Well, you may need to hear from some men of God

Undoubtedly, it connotes a psychological state of the non-empowered. The woman is obliged and the dictator to whom she is obliged is no other than the dominating male (men of God) in order for the dominant paradigm to be sustained. Coming from a female to other females seems like a complicit role-taking (compare Keating's (1998) argument that women actually disempower themselves). At play also is the effectiveness of the conditioned power of religion. Even though it has been argued by post-modernists that religion is losing its grip on social discourse to control the populace to medicine, which has become the new means of controlling people (Kirby et al 1997), within the Nigerian social milieu, religion is still a very powerful force of social control. This accounts for the power it continues to exert on the way women dress. However, the more dangerous of its effect is the violence it breeds against women in terms of declaring death sentences against them in Northern Nigeria, even where the 'offence' (adultery, so called) committed involves a male too.

This particular occurrence was, however, also treated as a probability item. This is 
because the modal may need to could also express the fact that the women should listen to the men if they think the men's advice is useful to them. It would be good for them to take the advice in such an instance, but only if they have the inclination to see its utility. Such may be a more assertive mindset.

In addition, considering Halliday and Matthiessen (2014) discussion on the degree of obligation and degree of inclination being dependent on modal assessment, one may view this particular case as that of 'potentiality' (p. 179) of the obligation through preceding need to with may. As such, the syntactic ordering of the modal structure has implication for their semantic content here. Nonetheless, the negative form, they claim, is the more common form of the need modal. This is positively presented by the choice of the preceding may element in this particular case.

In the same vein, TP02(4) may also be linked to the complicity of keeping the woman powerless through putting her under obligation to the male by other females. She was told that once she marries a man, she has lost all volition to decide her fate.

TP02(4) If you have agreed to bear a man's name you must submit...

This does not look like a very powerful position. This position that expects a woman to automatically become subject to a man because she married him is delineated by a woman that is ready to make the woman sustain the dominant paradigm.

In terms of ability, the two modals can and can't occur as showing the speaker seeing her ability to perform certain tasks. In NN03(1) this ability is denied in the verbal act but in NN03(2) the addressee is ascribed with the ability to undermine the columnist's own ability to 'invent' something.

NN03

(1) I can't really say why, but this general opinion worries me

(2) I hope somebody can help me with some answers

It seems then that the ability of the woman in this sense is non-existent in relation to the audience that is deemed more powerful. In TG03, even though the modal can is actually used, the speaker undermines this by claiming that she is helpless in the face of the addressee's lack of confidence in her ability. Thus, she has the willingness to act but the capability is taken from her by the uncooperative male that undermines this ability through his ideological posture of seeing her as actually lacking this power. An extract from the article illustrates this.

In the work place the major problem is acceptability. Even the people you work with actually feel you are a woman, that they have somebody 
like you at home. Some people come here and they expect to see a man. A man came in one day and said "I don't want to discuss with you." And I asked him why? He was asking if I was really the MD. He was that direct. And I told him, "Sorry sir, I would have really loved to help you in your inquiries, but since you don't want to talk to me, there is really nothing I can do." (TG03)

It may, however, be mentioned that her pointedly making the verbiage of showing the addressee his own imprudence for such a chauvinistic ideological stance shows that she truly possesses the ability and believes in it herself. Only the negative attitude of the male to it may sometimes frustrate her chance of manifesting it, if she allows it. She thus presents herself as being superior in mind to the focus of the addressee.

It is also observed that in many other cases where the woman's ability is undermined, it is usually done through modal adverb. Minimisation is the usual means of doing this.

TG03 And I told him, 'sorry, sir, I would have really loved to help you in your enquiries but since you don't want to talk to me there is really nothing I can do'

TP09 The old woman can hardly feed herself, let alone these little ones

TG03 has really as a means of reducing the effectiveness of the woman's ability and willingness to act. TP09 has hardly as the device to show the almost non-existence of the old grandmother's ability to provide for herself let alone her grandchildren. This of course led to her over-stretching herself in all ramifications due to her sense of obligation to the orphans.

Intensification, on the other hand, is expected to increase the effectiveness of the ability. It actually succeeds in doing this in showing the willingness and readiness of some of the women to perform some actions in the future. Such is the case of promptly used in TP14 by the writer to warn men of not only her ability to marry them if they meet her need of being able to cook but also making sure she carries it out without delay.

TP14 ...the day I find a man, who is not only able but lovingly and willingly enjoys cooking, I shall promptly seduce him and marry him sharp sharp!

She asserts:

After my clinic, I did more HIV talk at the General Hospital with some people living with HIV after which I went with the organisers to their house and was treated to a beautiful dinner cooked by men. How I wish 
there were more cooking-men out there. Usually, those who claim to love cooking stop as soon as they get married, claiming it's too much to do after a hard day (as if their wives had easy days). Warning, MEN BEWARE: the day I find a man, who is not only able but lovingly and willingly enjoys cooking, I shall promptly seduce him and marry him sharp sharp! (TP14)

As noted above, however, the eventuality of this action can only be accessed through a real future occurrence. TG03 has the actuality of the event expressed through the employment of actually.

TG03 I have actually had people come into my office and when they see me, they ask for the MD

In the case of NT07, the intensification makes the woman subsumed to an object like a skirt as source of help for her to gain recognition in the public space.

NT07 ...if properly sown and combined with nice top can make you the center of attraction wherever you go

It is not a seeming powerful state. Nonetheless, the most surprising of the intensification modal adverbs is just as in you just have to manage.

TG01 ...if anybody says they don't find it difficult to combine the home and office, that would not be the whole truth

TG01 But you just have to manage both

It increases the woman's powerlessness instead of her power base. It magnifies the fact that she is helpless to change a thing concerning her disadvantaged position in the society. This powerlessness is lodged in the mind and gets effectively projected through that modal. It is definitely a not too assertive position to occupy within the Nigerian society.

In terms of habitual modality, the one considered really important is that of used to in TP02(1).

TP02(1) I used to think that submission was oppression until

The addresser considers the more independent way of thinking as only relevant in the past before "God gave her insight" to the fact that submission is not oppression. She notes: 


\begin{abstract}
Reverend Mrs Ada Omoniyi, a marriage counsellor, who anchors the Complete Woman Telecast programme on Silverbird Television, Lagos, said submission is not oppression but a way out for wives to succeed in life and become friends of God. "I used to think that submission was oppression until God gave me an insight into the real meaning of this divine law," she began, with a serious look. "I now see it as the way out for wives to succeed in their marriage." (TP02)
\end{abstract}

Not surprisingly then, her advice to the woman is that she is under obligation to submit to the man's maltreatment because the volitionality of her freedom lies solely with God. Essentially, this implies that the subjection of the woman and her noticed complicity lies mainly in her thinking process. Her change of mind led to her becoming an accomplice in the social cognition that wishes for the female's continued subjugation, even to practices harmful to her wellbeing.

One is, however, not surprised as her office as a religious counsellor may not leave her with much choice in the matter. She is only doing her religious obligation. An extension of this obligation to men to stop 'beating' and harming the female will probably reduce the contention over 'submitting' in the first place. For then, mutual respect will place on both parties' equal obligation and a sense of belonging. Her telling the woman that any act of self-defence or attempt to free herself from the bondage can only make it worse [TP02(3)] apparently testifies to the fact that the social cognition of the dominant paradigm is a strong one here. Patriarchal ideology thus holds sway while appearing common sensical (Wodak 2001).

She adds:

"There are many ways you can go about saying your mind. I believe a wife should learn how to pray her through, but don't fight him or nag him. Or don't you know that you don't get anything by fighting? You will make things worse by doing that. And the man, of course, being the head of the family can actually relegate you to the background. (TP02)

In the same vein, one may deduce that used to in TG03(4) is a sign of the interviewee having given up her independence to fall in line with the expected behaviour in the Nigerian society.

TG03(4) I used to act martial-like sometimes

Her forcefulness probably gets mellowed down with age or her succumbing to the dominant paradigm. One clear thing, however, is that she voluntarily voided herself of this assertiveness she had as a younger person, and that is why she adds that she manages the situation of male chauvinism as best as she can. 
TG03(3) But rather than get upset, she says she manages the situation as best as she can

Probably, letting her male 'assailants' know her true feelings about the situation may force them to be the ones to fall in line. But then, she is a business woman, she may thus need a lot of caution in dealing with the negative inclination of her clients.

Next to be discussed is futurity and willingness in connection with the article in TP02 just analysed above. The only really volitional element with the possibility of actuality is will.

TP02

(2) Endeavour to do your own part by submitting and God will fight (the man) for you

(3) You will make the case worse

However, the use of the modal has God as the one to certainly and willingly act in the future on behalf of the woman as long as she continues to obligingly submit. Volition is thus taken from the woman and given to a force above and outside her.

It certainly is difficult for a bruised wife who has been humiliated by her husband in several ways, to abide by this law of submission. Does it not sound like a mission impossible? "Well, what I often tell wives is that if you do your own part, God will fight for you," she said.

Once again, the only volitional certainty in the following clause is that of an outside agent. Should the woman dare to attempt a defence of her dignity on her own, she may get a worse off scenario. Any expression of volitional act could result in the woman getting a worse deal; and this is a thing of high probability in terms of actuality. This does not strike one as a powerful position.

The modals, would have and wouldn't have, represent two probability items that indicate the possibility of avoidance of hurt to the woman in TG14 and TG09. In the first place, the female might have still been alive if not for the unscrupulous activities of the merchants of death.

TG14

(1) As a scientist, I knew if the antibiotics was genuine she would have been fine

(2) And Vivian would have been alive today

But in TG09, the woman's hurt and anger might have been assuaged if the male had 
not proved deceitful and unreliable. She gave her all and had herself scalded for it. She might not even have minded the hurt if the male had taken up his responsibility to their child. As much as TG14

"You see, most of us have suffered from the effects of fake drugs," she said. She paused again and resumed in resignation. "The best of all my sisters died in the ' 80 s because she was taking fake insulin. And she was diabetic. Her blood sugar could not be controlled. She got very ill. She had an infection. She needed antibiotics. We bought some antibiotics and she never responded to it. And as a scientist, I knew that if the antibiotics was genuine, she would have been fine. And Vivian would have been alive today."

presents a case of high probability that was not originally targeted at the woman because of her being a woman - anyone could have been a victim of fake drug - this cannot be said of TG09. The most interesting part of her claim is that she does not consider her being used, abused and dumped as material. She moans in the article:

Some men could be so heartless! But Charles, why? Why? ... I wouldn't

have been this bitter and disappointed if not that Charles decided to ignore his responsibility on our only son. (TG09)

Probably, she feels she deserves it or she does not consider herself as meriting a better condition. Her pain would have been ameliorated if only the 'deceitful' man had acknowledged her child and cared for it. This appears a servile mindset. It is not positive, and neither is it assertive.

\section{Findings}

In all, the modals employed in the articles assessed show a preponderance of putting the woman under obligation to act. Most do not give her a chance for the exercise of her volitive ability. Instead, this ability is often undermined. Where attempt is made to shake off the albatross of the thinking system of the cultural lore, the obstructing male is there to hinder or direct. However, whenever the male does not stand to dictate to the woman society's cultural expectations, other females take up the role, in order to keep society one, probably. The most unsettling is the seeming acceptance of the situation of her being short-changed as normal. In many cases, she does not even seem to consider the abusive situation as abnormal. This complicit hegemonic mindset predominates in the modal choices of most of the women, their economic and educational attainment notwithstanding. It is only in very few cases that subversion of the hegemonic order seems to infiltrate the fog of the acceptance of the status quo. Should one consider this as a silver lining in the sky? Time will tell. 
The examination of the modal choices in the syntactic structures of the Nigerian women in the newspaper articles analysed does not show that the woman has moved far from the powerless state. Rather, attempts to perpetuate the state of non-assertiveness of her individuality predominate. The pessimism of post-modernist thinking on the tenacity of the patriarchal order appears justified by the infinitesimal nature of these women's display of assertiveness in their modal choices. Nonetheless, accepting defeat should mean a furtherance of the gains of patriarchy. This is backward integrating.

\section{Conclusion}

This paper set out to investigate the meaning content of the modal verbs as employed by Nigerian women in select Nigerian newspapers. The interest is to find out if twenty years after the Beijing conference, the women within the Nigerian sociocontext have been able to overcome the patriarchal structure and learnt to make use of language to express the new self in terms of power repositioning as a power broker within the Nigerian social milieu. Looked at from the angle of Daniel (2016) finding that the African woman had not always been an underdog in her social relationship with men, it appears proper to get worried about the way the modern woman seems to carry herself in the social milieu. In addition, with the recent focus on women empowerment and gender mainstreaming in order to correct the African women's loss of their enviable social position, an assessment of the level of the success of attempts at women empowerment within the Nigerian society in the context of the global drive for it appears in order.

The study employed the meaning content of the English modals within syntactic structures as the basis of the investigation. It was found that the propositional contents of the English modals in sentences as used by Nigerian women have not moved much in terms of their meaning content since after the Beijing conference. The meaning content unearthed and deciphered from the syntactic structures in their linguistic usages essentially portrays women that are self-effacing and hegemonically consenting to the patriarchal social order within the Nigerian society. It is therefore suggested that except women learn to assert themselves, the social structure will continue to disfavour them. However much more is the finding that modals can be effectively meaningful beyond the seeming grammatical functioning that is usually ascribed to them. 


\section{References}

Asante, Ben. 2006. "I'll Shatter the Mystique of Under-performance." The Guardian. Sunday, January 22: 23.

Awake! 2008. "Violence against Women: A Global Problem." Violence against Women: What is the Bible's View? New York: Watchtower Bible and Tract Society. January, 89 (1): 3-7.

Daniel, Iyabode Omolara. 2008. The Linguistic and Pictorial Representation of Nigerian Women's Assertiveness in Selected Nigerian Newspapers. Doctor of Philosophy Thesis, University of Ibadan, Ibadan, Nigeria.

Daniel, Iyabode Omolara Akewo. 2016. "How did we Get Here? A Historical Profile of the African Woman". Gender and Behaviour 14 (3): 7693-7710.

Galbraith, John Kenneth. 1983. The Anatomy of Power. London: Hamish Hamilton Ltd. Hakutani, Yoshinobu. 1978. "The Features of Modals in English Syntax." Linguistics. 209: 59-69.

Halliday, Michael Alexander Kirkwood. 1985. An Introduction to Functional Grammar. London: Edward Arnold.

Halliday, Michael A. K. and Christian M. I. M. Matthiessen. 2014. Halliday's Introduction to Functional Grammar, 4th edn. London and New York: Routledge.

Keating, Elizabeth. 1998. “A Woman's Role in Constructing Status Hierarchies: Using Honorific Language in Pohnpei, Micronesia." International Journal of the Sociology of Language. 129: 103-115.

Kirby, Mark, Warren Kidd, Francine Koubel, John Barter, Tanya Hope, Alison Kirton, Nick Madry, Paul Manning, and Karen Triggs. 1997. Sociology in Perspective. Oxford: Heinemann Educational Publishers.

Lorde, Audre. 1994. "The Master's Tool will Never Dismantle the Master's House." The Woman Question. 2nd edn. London, Thousand Oaks, New Delhi: Sage Publications. 366-368.

Opara, Stephen C. 2005. "Mood Structures in Selected Clauses in Buchi Emecheta's Second-Class Citizen." In Perspectives on Language and Literature, edited by M. Olateju and L. Oyeleye, 117-133. Ile-Ife: Obafemi Awolowo University Press Ltd.

Osisanwo, Wale 1999. An Introductory Analytical Grammar of English - A Systemic Approach. Lagos: Femolus-Fetop Publishers.

Palmer, Frank R. 1977. "Modals and Actuality." Journal of Linguistics. 13.1: 1-23.

Palmer, Frank R. 2001. Mood and Modallity. Cambridge: Cambridge University Press.

Papafragou, Anna. 1998. Modality and Semantics-Pragmatics Interface. PhD Thesis, University College, London.

Reah, Danuta. 1998. The Language of Newspapers. London: Routledge.

Von Fintel, Kia. 2006. "Modality and Language." In Encyclopedia of Philosophy Second Edition, edited by Donald M. Borchert. Detroit: MacMillan Reference 
USA.

Wodak, Ruth. 2001. "What CDA is about - A Summary of its History, Important Concepts and its Developments." Methods of Critical Discourse Analysis: Introduction to Qualitative Methods. Ruth Wodak and Michael Meyer. Eds. London: Sage Publications Ltd. 


\section{Appendix}

NN02

(1) I have always wanted to serve and contribute my quota to the development of the nation

(2) If I do this I will by extension touch the lives of Nigerians

(3) I always felt very bad whenever I encountered children hawking on the streets

NN 03

(1) I can't really say why, but this general opinion worries me

(2) I hope somebody can help me with some answers

NN 04

(1) I strongly agree to the doctrine of child-discipline

NN10

(1) I must confess that the person I married is part of the contributory factors to what I have become today

(2) At times, we would have to go to the secretariats of the industrial unions

NT 01

(1) ...yet I always feel like hitting men who maltreat fellow sisters

\section{NT07}

(1) ...if properly sown and combined with nice top can make you the center of attraction wherever you go

(2) Pencil skirt will look sexy on you

(3) The right skirt will surely do the trick

\section{NT11}

(1) I will pray about it and ask pastors to pray along with me

(2) Then if I am convinced, I will go for it

(3) I will wait on God for confirmation

(4) I must also be on the look out

NT12

(1) I can imagine how small he must have felt

(2) May I seize this opportunity to say sorry to those...

(3) If I should reproduce the messages here...

TC 01 
(1) I must say it's quite challenging

(2) But really my best moments are always the time I spent with my family

TC02

(1) I used to have this friend in school

TC05

(1) I almost left her there

TC06

(1) I say 'not sure' because there are mainstream cultural things and tons of what I will describe as 'subculture' events

(2) ... do not show they are movies I can enjoy

TD05

(1) I would just pretend until it is over

(2) They do call me and I would go to them

(3) I will quit as soon as God answers my prayers

(4) I will use it to establish business

TD06

(1) I must do the work required of me to remain there

TD07

(1) You cannot afford to disappoint

(2) I always feel at home, because when we attend labour meetings...

(3) You have to work for that trust

(4) You cannot go into politics without the approval of your family

(5) You have to get the approval of your children

TD09

(1) I would not be able to write weekly anymore due to time constraints

(2) That is not to say I would totally cease writing

TD13

(1) ... a quick stop over in Surulere to pick up the lace blouse I was going to wear the following morning

(2) When it finally dawned on her that she could actually do something about it, someone opened the door and moved the stick out of her way

(3) I don't know what he saw in my eyes, but with hindsight, I don't know what I would have done... 
(4) ...but I would hate to have to leave that chance

TD14

(1) I can never get it

(2) I would have thought with the fact that they had several others, they would be more tolerable of their partners' philandering

\section{TD15}

(1) I was convinced that I could go on to greater success in life

(2) Furthermore, I have always been a very independent person

(3) ... and believed that I would still become successful in spite of this set back

(4) My advice to fellow women is that they should be strong

(5) I must emphasize that women should be strong

(6) Women must always remember that...life must go on

(1) ... at a point, she had to choose between the job and reuniting with her family and career

(2) ... she had to cope with her career as well as building a home

(3) ... but if you manage both properly, you would have a balance

(4) ... if anybody says they don't find it difficult to combine the home and office, that would not be the whole truth

(5) But you just have to manage both

TG02 TG03

(1) I have always seen acting as something that is within me

(1) I have actually had people come into my office and when they see me, they ask for the MD

(2) ...that in this day and age that people can still reason like that

(3) But rather than get upset, she says she manages the situation as best as she can

(4) I used to act martial-like sometimes

(5) And I told him, 'sorry, sir, I would have really loved to help you in your enquiries but since you don't want to talk to me there is really nothing I

can do'

TG 04

(1) Women should refuse to go out...

(2) Mothers should ask their children in power...

(3) Wives should ask their husbands in power...

(4) Sisters should do something to brothers 
TG09

(1) I wouldn't have been this bitter and disappointed if not that Charles had decided to ignore his responsibility on our only son

(2) I couldn't deny the act again

TG14

(1) As a scientist, I knew if the antibiotics was genuine she would have been fine

(2) And Vivian would have been alive today

(3) The opportunity to deal with these criminals is a life opportunity that I should make the best use of.

TG16

(1) And Tess could not help herself

(2) ... she should look at the plays she has written and she would see her mother in them

(3) But the family insisted that permission must be sought from them before the dance would begin

(4) ...daughters of the clan who should be by my side traditionally, supported the men this time

TG17

(1) She contended that government should have sought out other possible solutions

TG18 a.

(1) I would have loved to spend much time with them than I am doing presently

(2) In combining household obligations with politics, you have to understand that politics is demanding

(3) Sometimes, you have to stay late nights for meetings

(4) One, you have to chase this one and that one, and then the whole assignments

TG18 b.

(1) I always hold regular meetings with them

(2) Before I decide, I would allow people to air their views

(3) I believe you have to prove yourself

TP 02

(1) I used to think that submission was oppression until

(2) Endeavour to do your own part by submitting and God will fight ${ }^{\text {(the man) }}$ for you

(3) You will make the case worse

(4) If you have agreed to bear a man's name you must submit... 
TP03

(1) ...Well, you may need to hear from some men of God

TP 05

(1) My siblings would invite their friends over to ${ }^{(T h e y)}$ watch me dance, sing and

(2) ${ }^{(\mathrm{I})}$ generally make a fool of myself

TP09

(1) The old woman can hardly feed herself, let alone these little ones

(2) She has to get food on credit

(3) I will never publish your name anywhere

(4) I have to do personal meetings and interviews to make sure

(5) I will keep you updated

TP14

(1) ...the day I find a man, who is not only able but lovingly and willingly enjoys cooking, I shall promptly seduce him and marry him sharp sharp!

TP17

...the doctor recommended anti-depressants but I'm afraid I might get hooked on them People say they cannot talk about HIV because of stigma

There will always be stigma until we, who are infected speak out!

...nobody out there ... will fight your battle

The best they can do is to give us moral and/or financial support

NOTE: This paper is extracted from my $\mathrm{PhD}$ Thesis titled: THE LINGUISTIC AND

PICTORIAL REPRESENTATION OF NIGERIAN WOMEN'S ASSERTIVENESS IN SELECTED NIGERIAN NEWSPAPERS 